\title{
ДОСЛІДЖЕННЯ З ЕКСПЕРИМЕНТАЛЬНОГО ВПРОВАДЖЕННЯ ЕЛЕКТРОННИХ РЕЦЕПТІВ В УКРАÏНІ
}

\author{
๑Б. Л. Парновський, О. М. Заліська, А. І. Бойко, І. Ю. Рев'яцький, \\ М. В. Слабий, Г. Ю. Яцкова, Н. М. Максимович \\ Львівський національний медичний університет імені Данила Галицького
}

\begin{abstract}
Резюме: дослідження кафедри організації та економіки фармації і технології ліків ЛНМУ ім. Данила Галицького за останні 35 років щодо можливості застосування в охороні здоров'я України електронних рецептів включають стадії методологічного, організаційно-методичного, технічного забезпечення процесу. Представлено результати фактичних спостережень використання електронних рецептів на готові та екстемпоральні лікарські засоби на регіональному рівні.
\end{abstract}

Ключові слова: електронний рецепт, фармацевтична діагностика, фармакоекономічна оцінка електронних рецептів.

Вступ. ВООЗ та Міжнародна Федерація фармацевтів у своєму принципово важливому документі «Належна аптечна практика: Стандарти якості аптечних послуг. Настанова ВООЗ/МФФ (WHO/FIP), 2011» констатують, що провізори (фармацевти) «повинні аналізувати і оцінювати всі отримані паперові або електронні рецепти з урахуванням терапевтичних, соціальних, економічних та правових аспектів призначень» [11]. Розглянемо деякі теоретичні обґрунтування переходу до електронних рецептів на лікарські засоби (ЛЗ).

у 1979 р. Б. Л. Парновський та співавт. опрацювали методику підготовки рецептів до автоматизованої обробки, що полягала у кодуванні назви (номера) лікарського закладу, віку та статі хворого, спеціальності лікаря, кодів препаратів (державних), кодів лікарських форм, виду рецепта (готовий або екстемпоральний лікарський засіб). Система промодельована на сукупності 995 рецептів на готові ЛЗ з використанням EOM EC-1022 [12].

у 1981 р. Б. Л. Парновський та співав. провели моделювання діалогової системи, призначеної для автоматизованого контролю доз і сумісності папаверину гідрохлориду та дибазолу 3 іншими ЛЗ в одному рецепті [10]. у 1986 р. у кандидатській дисертації Л. П. Смирнова опрацювала базу даних про лікарські засоби, ії експериментальна модель апробована в обчислювальному центрі Львівського обласного статуправління на EOM EC-1035, на прикладі обробки рецептів на еуфілін [18]. у 1992 р. у кандидатській дисертації М. В. Слабий функціонально промоделював використання експертних систем на ЕОМ для контролю правильності оформлення рецептів [18].
У XXI ст. спостерігається світова тенденція широкого використання електронних рецептів. Досвід провідних країн світу свідчить про фармакоекономічні вигоди від електронного призначення ЛЗ, коли за допомогою Інтернету точно, без помилок і зрозуміло виписаний друкованим способом рецепт безпосередньо від лікаря передається в аптеку. Так, у США в 2003 році вимоги щодо електронної системи призначень ліків було включено у Закон про модернізацію медичної допомоги Medicare (MMA). у 2006 р. Інститут медицини США констатував, що використання електронних рецептів забезпечило: скорочення помилок у призначенні та їх корекцію з участю провізорів (фармацевтів); підвищення обізнаності лікарів про е-виписування ліків; покращення безпечності лікування хворих; скорочення витрат на призначення ліків. У 2006 р. встановлені стандартні вимоги до електронних призначень при затвердженні правил оформлення та відпуску електронних призначень відповідно у 2009 р. [23].

У цей період проводилися фармакоекономічні оцінки впровадження електронних рецептів у США. За даними літератури, електронна система е-призначень дозволяє лікарям обирати ліки нижчої вартості, заміняти на генерики, що економить 845 тис. доларів США на 100 тис. пацієнтів на рік [23]. Було виявлено, що електронні рецепти виписували лікарі молодшого віку, в більшості терапевти, педіатри та сімейні лікарі, які формували 3/4 сукупності електронних призначень. У США, серед 17,4 млн досліджених рецептів, 212 тис. були призначені в електронному вигляді.

Досвід Швеції свідчить, що за 2008 рік економічна вигода від виписування електронних ре-

ISSN 2312-0967. Фармацевтичний часопис. 2015. № 1 
Інформаційні та інноваційні технології у фармації Informational and innovational technologies in pharmacy

цептів становила 95 млн євро. Також встановлено зменшення на 15 \% помилок при призначенні і дозуванні ліків для пацієнтів, що підвищило ефективність і безпечність фармакотерапії [21]. У цій країні станом на 2010 рік 42 \% призначень від лікарів до аптеки надходять в електронному вигляді через мережу Sjunet (надійно захищена та доступна тільки зареєстрованим лікарям) національної охорони здоров'я. Отже, впровадження електронних рецептів оптимізує їх фармацевтичну діагностику та має фармакоекономічні переваги.

Методи дослідження: методи фармацевтичної інформатики, побудови комп'ютерних баз даних та баз знань, аналіз споживання лікарських засобів, фармацевтична діагностика у системі «лікар-провізор».

Результати й обговорення. 3 врахуванням власних та міжнародних досліджень у 2011 році концепція впровадження електронного рецепту в Україні пов'язана з класичною фармацевтичною проблемою - попередження негативної побічної дії ЛЗ при одночасному застосуванні 3 використанням комп'ютерних технологій [1, 4, 17]. Загальні принципи класифікації взаємодії лікарських засобів деталізувала Г. Ю. Яцкова [8, 20]. Подальші дослідження доцільності електронних рецептів з врахуванням можливостей комп'ютерних технологій проводили у двох напрямах: 1) готові Л3; 2) екстемпоральні ЛЗ.

При експерименті щодо готових ЛЗ ми обрали соціально важливе захворювання цукровий діабет з позитивною динамікою поширеності в Україні та світі. Також фактором вибору були нові лікарські форми та способи застосування профільних ЛЗ. Доцільним було врахування напрямів подальшого розвитку фармацевтичної інформатики [3].

У плані першого напряму був аналіз розвитку методології фармацевтичної інформатики від комп'ютерних баз даних до баз знань [6]. При програмуванні фармацевтичних баз знань використаний досвід та моделі інформаційного забезпечення баз даних про лікарські засоби [19].

Бойком А. І. опрацьовані шляхи трансформації фармацевтичної інформації у фармацевтичні знання з використанням електронних рецептів. Загальна схема такого процесу наведена у публікації [7]. Стратегія прийняття рішення про можливість комбінованого застосування лікарських засобів наведена на прикладі комбінацій: глібенкламід + флуконазол; глібенкламід + атенолол / пропанолол / тимолол; інсулін + еналаприлу малеат + гідрохлортіазид; метформін + бісопролол [2, 5, 13].

Розглянемо схему функціонування опрацьованої нами моделі системи комп'ютерної діаг- ностики електронних рецептів в ланці «лікарпровізор» на більш складному методичному прикладі - одночасному призначенні трьох ЛЗ: репаглініду + гемфіброзилу + ітраконазолу. Відповідно опрацьованої нами моделі вердиктної системи та запропонованих рівнів її доказовості репаглінід (цукрознижувальний ЛЗ), гемфіброзил (гіпохолестеринемічний ЛЗ) та ітраконазол (протигрибковий ЛЗ для системного застосування) для одночасного прийому відпускати не можна. Причина: суттєве збільшення концентрації репаглініду в плазмі з наступною гіпоглікемією, що загрожує життю хворого. Рівень доказовості В. Джерело інформації: публікації у фахових журналах [21].

Експертно-діагностична (дорадча) система при цьому надає інформацію, що при одночасному призначенні репаглініду, гемфіброзилу та ітраконазолу, концентрація репаглініду у крові зростає майже у 20 разів, що може призвести до небажаної гіпоглікемії. В той час, коли подвійна комбінація репаглінід + гемфіброзил викликає 8-кратне підвищення концентрації репаглініду, а комбінація репаглінід + ітроконазол 1,4-кратне збільшення концентрації репаглініду в крові. Даний факт взаємодії описаний у публікації John R. Horn та Philip D. Hansten [23].

Функціонування фармацевтичної бази знань для інформаційного забезпечення прийняття рішення про можливість одночасного застосування проведено на прикладі лікарських засобів для лікування цукрового діабету: інсуліну, глібенкламіду, метформіну. Виокремлено факти взаємодії їх з окремими препаратами, алкоголем, які розподілено на потенційно небезпечні та ті, що не приводять до значних наслідків [7]. Передбачено комплекс взаємодії між лікувально-профілактичним закладом та аптекою, яка спеціалізується для таких хворих. Форми співпраці передбачають традиційні функції 3 інтеграції інформування хворих про профільні ЛЗ, аналізу споживання та визначення потреби в них. Додатковою функцією є довідкове та інформаційне забезпечення про фактори взаємодії ЛЗ. Для впровадження концепції електронних рецептів у практику А. І. Бойком у 2013 р. опрацьована авторська програма та проведено тематичне удосконалення «Інформатизація рецептурного обігу в Україні» для провізорів Тернопільської, Львівської, Хмельницької та Рівненської областей.

Організаційно-методичне забезпечення експерименту щодо одержання та фармацевтичної діагностики аптекою екстемпоральних рецептів розпочато у 2014 році [9]. Рев'яцький І. Ю. опрацював інформаційне забезпечення та алгоритм виписування електронних рецептів відпо-

ISSN 2312-0967. Pharmaceutical review. 2015. № 1 
Інформаційні та інноваційні технології у фармації Informational and innovational technologies in pharmacy відно до всіх вимог діючого наказу МОЗ України від 19.07.2005 № 360 [16]. На основі опрацьованих цим автором методичних рекомендацій «Комп'ютеризація інформаційного забезпечення екстемпорального виготовлення лікарських засобів в аптеках України», затверджених Проблемною комісією «Фармація» МОЗ та НАМН України (протокол № 89 від 18.02.2015 р.), промодельовані комп'ютерні бази даних «Прийом та аналіз екстемпоральних рецептів» та «Інформаційне забезпечення операцій технологічного процесу виготовлення ЕЛЗ» 3 інформаційними та контролюючими функціями щодо виписування екстемпоральних рецептів і виготовлення ліків в умовах аптеки, яка обслуговує лікарню та амбулаторних хворих [16].

Вирішується завдання з обліку варіантів рецептів (комбінацій інгредієнтів), що надійшли, АФІ, а при необхідності і допоміжних речовин. Одержання таких сумарних даних за суттєвий період часу (квартал, рік) дозволяє вивчати динаміку рецептури, появу ії̈ нових варіантів, а також прогнозувати потребу в окремих АФІ для виготовлення екстемпоральних ліків. База даних включає алгоритми ідентичних опрацювань інформації про АФІ та допоміжні речовини.

При наявності сукупності АФІ, які застосовуються для виготовлення різних екстемпоральних лікарських форм, можна глобалізувати проблему доказової фармації про їх раціональність. Основою таких заключень 3 врахуванням термінів довгострокових використань класичних АФІ (пепсин, протаргол, коларгол та ін.) та наявності можливих аналогів промислового виробництва (з врахуванням різниць у вартості аптечного екстемпорального та готового лікарського засобу), можуть бути результати клінічних спостережень, експертних оцінок у медичній та фармацевтичній літературі. Також можливе системне залучення аптечних працівників для оцінки якості. На основі фармакоекономічного підходу екстемпоральні рецепти, як правило, є менш вартісними і методологія фармакоекономічного аналізу, систематизована та впроваджена в Україні проф. О. М. Заліською, може бути адаптована до екстемпоральних рецептів як об'єктів [10]. Встановлено, що на да-

\section{Література}

1. Бойко А. І. Електронні рецепти: стан та перспективи використання / А. І. Бойко, Б. Л. Парновський // Новини медицини та фармації. - 2012. - № 4(402). - С. 28-29. 2. Бойко А. І. Концепція формування фармацевтичних знань (теоретичні та практичні аспекти) / А. І. Бойко // Фармацевтичний часопис. - 2012. - № 2 (22). C. 81-85. ний час при виготовленні екстемпоральних ліків через відсутність АФІ застосовують 58 готових лікарських засобів, з них 42 найменування становлять таблетки і капсули.

Доцільне комплексування в оцінці ефективності екстемпоральних рецептів провізорів з педіатрами, дерматологами, офтальмологами, лікарями інших спеціальностей, де часто зустрічається екстемпоральна рецептура, з можливою оцінкою оптимальності її використання. Наприклад, у 1981 р. кафедра організації і економіки фармації та технології ліків ЛНМУ імені Данила Галицького спільно з кафедрою дерматовенерології, Аптечним управлінням Львівського облвиконкому, Львівським міським клінічним шкірно-венерологічним диспансером опрацювала інформаційні та методичні матеріали для лікарів та фармацевтів, в яких багатоаспектно розглянуто профільні екстемпоральні лікарські засоби [15].

На нашу думку, у зв'язку з реформуванням фармацевтичного забезпечення перспективним $€$ поступовий перехід до використання сучасних електронних призначень та рецептів. Отриманий досвід свідчить, що електронні рецепти сприяють належному відпуску ліків за рецептами лікарів з врахуванням профілактики небажаних взаємодій, контролю обліку споживання і прогнозування потреби в лікарських засобах.

Висновки. 1. Доведена ефективність застосування електронних рецептів в охороні здоров'я України з врахуванням належного нормативного, організаційно-методичного та технічного супроводу.

2. Результати теоретичних досліджень з врахуванням фактора профілактики небажаних взаємодій лікарських засобів свідчать про доцільність диференційованих методик комп'ютерної обробки рецептів на готові лікарські засоби та рецептів на екстемпоральні лікарські засоби, що дозволяє обліковувати споживання та потребу в їх активних фармацевтичних інгредієнтах та допоміжних речовинах

3. Впровадження електронних рецептів на готові лікарські засоби для лікування діабету проведено у Тернопільській області, для екстемпоральних прописів - у Львівській області, про отримані відповідні акти впровадження.

3. Бойко А. І. Методика фармацевтичної діагностики електронних рецептів // Свідоцтво про реєстрацію авторського права на твір Державного департаменту інтелектуальної власності № 39404 від 01.08.2011. 4. Бойко А. І. Результати експерименту з впровадження електронних рецептів на регіональному рівні / А. І. Бойко // Фармацевтичний часопис. - 2014. -

ISSN 2312-0967. Фармацевтичний часопис. 2015. № 1 
Інформаційні та інноваційні технології у фармації Informational and innovational technologies in pharmacy

№ 1(29). - C. 98-102.

5. Бойко А. І. Результати експерименту з впровадження електронних рецептів на регіональному рівні / А. І. Бойко, Б. Л. Парновський // Фармацевтичний часопис. - 2014. - № 1(29). - С. 98-102.

6. Бойко А. І. Розвиток методології фармацевтичної інформатики від комп'ютерних баз даних до баз знань / А. І. Бойко, Н. А. Прилипко, Б. Л. Парновський // Ліки України плюс. - 2010. - № 2. - С. 76-78.

7. Бойко А. І. Трансформація фармацевтичної інформації у фармацевтичні знання та комп'ютерних баз даних в бази знань на прикладі створення експертних систем по взаємодії лікарських засобів, що функціонують на основі методів доказової фармації / А. І. Бойко // Фармацевтичний часопис. - 2011. - № 3. - C. 83-89.

8. Електронний рецепт як елемент упровадження засад фармацевтичної діагностики / Б. Л. Парновський, Г. Ю. Яцкова, М. В. Слабий [та ін.] // Управління, економіка та забезпечення якості в фармації. - 2011. № 2. - C. 28-33.

9. Інформаційне забезпечення системи виписування електронних рецептів / І. Ю. Рев'яцький // Управління, економіка та забезпечення якості в фармації. 2013. - № 4. - C. 48-52.

10. Заліська О. М. Фармакоекономіка і раціональне використання ліків: навчальний посібник ; за ред. Б. Л. Парновського. - Львів: Афіша, 2014. - 252 с.

11. Моделювання комп'ютерної (діалогової) системи контролю рецептів (доз та сумісності інгредієнтів) / Б. Л. Парновський, Л. В.Чернецький, Л. І. Маслова [та ін.] // Фармацевтичний журнал. - 1981. - № 5. - С. 62-66. 12. Належна аптечна практика: Стандарти якості аптечних послуг. Настанова ВООЗ та Міжнародної Федерації фармацевтів (FIP), 2011 (Joint FIP/WHO guidelines on good pharmacy practice: standards for quality of pharmacy services from the WHO technical report series, No. 961, 45th report of the WHO Expert Committee on specifications for pharmaceutical preparations World Health Organization 2011). - [Електронний ресурс]: Режим доступу: https://www.fip.org/files/fip/WHO/ GPP\%20guidelines\%20FIP\%20publication_final.pdf 13. Про методику автоматизованої обробки рецептури / Б. Л. Парновський, Л. Т. Ходосевич, О. Ф. Черкашин [та ін.] // Фармацевтичний журнал. - 1979. - № 4. - С. 64-67.

14. Погляд на проблеми реалізації пілотних проектів щодо запровадження державного регулювання цін на протидіабетичні лікарські засоби з врахуванням сучасних проблем лікарського забезпечення хворих на цукровий діабет / А. І. Бойко, Б. Л. Парновський, Р. Я. Мостовий [та ін.] // Новини медицини та фармації. - 2014. - № 7. - 8(402). - С. 25.

15. Применение лекарственных средств в дерматологии : информационные и методические материалы для врачей и фармацевтов / [Знаевская А. В., Парновский Б. Л., Зайченко А. И. та ін.]. - Львов. - 1981. $-74 \mathrm{c.}$.

16. Рев'яцький І. Ю. Опрацювання інформатизації процесу фармацевтичної допомоги аптек / І. Ю. Рев'яцький, Б. Л. Парновський, Н.А.Прилипко // Фармацевтичний часопис. - 2014. - № 4. - С. 68-72.

17. Розвиток теорії фармацевтичної інформатики та викладання цієї дисципліни в Україні / Б. Л. Парновський, М. В. Слабий, О. М. Заліська [та ін.] // Клиническая информатика и телемедицина. - 2008. - Т. 4, вып. 5. - С. 60-63.

18. Слабый М. В. Моделирование информационного обеспечения экспертных систем на ЭВМ для провизоров-организаторов: автореф. дисс. на соискание ученой степени канд. фармац. наук: спец. 15.00.01 «Технология лекарств и организация фармацевтического дела» / М. В. Слабый. - Львов, 1992. - 21 с.

19. Смирнова Л. Ф. Информационное обеспечение баз данных о лекарственных средствах: автореф. дисс. на соискание научн. степени канд. фарм. наук: 15.00.01 / Л. Ф. Смирнова. - Львов, 1986. - 24 с.

20. Яцкова Г. Ю. Фармацевтична діагностика / Г. Ю. Яцкова, Б. Л. Парновський // Фармацевтична енциклопедія / Голова ред. ради В. П. Черних. - 2-ге вид., перероб. і доповн. - К. : «МOPIOH», 2010. - 1632 с.

21. Descriptive report on site study results: Apoteket and Stockholm County Council, Sweden - eRecept, an ePrescribing application // eHealth Impact 7.2 DG INFSO October 2006 [Електронний ресурс]. - Режим доступу: http://www.ehealth-impact.org/case_studies/ documents/ehealth-impact-7-2.pdf

22. Effects of gemfibrozil, itraconazole, and their combination on the pharmacokinetics of repaglinide: potentially hazardous interaction between gemfibrozil and repaglinide / M. Niemi, J. Backman, M. Neuvonen [et al.] // Diabetologia. - 2003. - № 46. - P. 347-351.

23. E-Prescribing.-[Електронний ресурс]: Режим доступу: www.cms.gov/Medicare/E-Health/Eprescribing/ index.html? redirect=/ eprescribing

24. Horn J. R. Triple Drug Interactions / John R. Horn, Philip D. Hansten // For a list of references, go to www.PharmacyTimes.com/issue/pharmacy/2011/ January 2011 [Електронний ресурс]. - Режим доступy: http://www.hanstenandhorn.com/hh-article01-11.pdf

ISSN 2312-0967. Pharmaceutical review. 2015. № 1 
Інформаційні та інноваційні технології у фармації

Informational and innovational technologies in pharmacy

\title{
ИССЛЕДОВАНИЯ ПО ЭКСПЕРИМЕНТАЛЬНОМУ ВНЕДРЕНИЮ ЭЛЕКТРОННЫХ РЕЦЕПТОВ В УКРАИНЕ
}

\author{
Б. Л. Парновский, О. Н. Залиская, А. И. Бойко, И. Ю. Ревяцкий, Н. В. Слабый, \\ Г. Ю. Яцкова, Н. Н. Максимович \\ Львовский национальный медицинский университет имени Данила Галицького
}

Резюме: Исследования кафедры организации и экономики фармации и технологи лекарств ЛНМУ им. Данила Галицкого за последние 35 лет в сфере возможностей применения в здравоохранении Украины электронных рецептов включают стадии методологического, организационно-методического, технического обеспечения процесса. Представлены результаты фактических наблюдений использования электронных рецептов для готовых и экстемпоральных лекарственных средств на региональном уровне.

Ключовые слова: электронный рецепт, фармацевтическая диагностика, фармакоэкономическая оценка электронных рецептов.

\section{STUDY OF EXPERIMENTAL USING OF ELECTRONIC RECIPES IN UKRAINE}

B. L. Parnovskyy, O. M. Zaliska, A. I. Boyko, I. Yu. Revyatskyy, M. V. Slabyy, G. Y.Yatskova, N. M. Maksymovych

\section{Lviv National Medical University by Danylo Halytsky}

Summary: researches of Department of Management and Economy of Pharmacy and Medicine Technology, Postgraduate Faculty, Danylo Halytsky Lviv National Medical University during the last 35 years about the possibility of electronic recipes using in Ukraine healthcare include the stages of methodological, organizational-methodical, technical support of process. Results of actual supervisione of electronic recipe using for medicines and extemporaneously compounded medicines at regional levels are presented.

Key words: electronic recipes, pharmaceutical diagnostics, pharmacoeconomic evaluation of electronic recipes.

Отримано 24.03.2015

ISSN 2312-0967. Фармацевтичний часопис. 2015. № 1 